\title{
SOCIAL ENTREPRENEURSHIP AS A FORM OF SOCIAL WORK FOR THE SOCIAL COHESION OF SOCIETY
}

\author{
Valters Dolacis, Skaidrite Gūtmane, Dace Deizija Rode \\ Latvian Christian Academy (Latvia)
}

\begin{abstract}
Social entrepreneurship serves as one of the social techniques for the social cohesion of disadvantaged and marginalised groups in society, and therefore can be used as a practical method in the field of social work. Social entrepreneurship provides an operational platform for the renewal of people's self-dependence skills, by learning to do things together, which is a relevant motivational aspect for socially marginalised people in solving their social and personal problems. Thus, the social cohesion of disadvantaged and marginalised groups of society by being involved in social entrepreneurial activities, and thus being placed in the sphere of the productive economy at the level of the community, contributes to the development of the local community, giving citizens the socially active status of being active protagonists in their destiny and their local community. However, the renewal of a person's social functioning, achieved by involvement in social entrepreneurial activities, covers a person's life holistically, starting with the person's inner processes that lead to forming external social relationships. Therefore, the analysis of this process in the article involves taking an anthropological perspective on activating people's inner resources and human potential in the activities of social enterprises, which also shows the dimension of social entrepreneurship as a tool for personal development. The aim of the article is to explore the phenomenon and practice of social entrepreneurship in the context of social work, where social entrepreneurship can be used as an innovative approach as a tool for the development of the community, and for the transformation on a personal level of practitioners and people involved in entrepreneurial activities.

KEY WORDS: social entrepreneurship, social work, social cohesion, social and spiritual functioning, human potential, inner resources of a person, reciprocity.
\end{abstract}

\section{Anotacija}

Socialinis verslumas yra viena iš socialinių technologijų, skirta socialiai nuskriaustų ir marginalizuotų visuomenès grupių socialinei sanglaudai, jis gali būti taikomas kaip praktinis socialinio darbo metodas. Socialinis verslumas sudaro galimybes žmonèms savarankiškai atnaujinti ịgūdžius, mokantis veikti kartu, tai svarbus motyvacinis aspektas socialiai marginaliems žmonėms sprendžiant savo socialines ir asmenines problemas. Taigi nepalankioje padètyje esančių marginalizuotų visuomenès grupių socialinė sanglauda, dalyvaujant socialinio verslumo veikloje ir taip bendruomenès lygiu patenkant ị gamybinès ekonomikos sriti, prisideda prie vietos bendruomenès aktyvumo skatinimo. Plètodamas socialinį verslą asmuo gyvena visa apimantị gyvenimą, pradedant vidiniais žmogaus procesais, kurie skatina išorinių socialinių santykių formavimąsi. Tad šio proceso analizè straipsnyje apima antropologinę žmogaus vidinių išteklių ir žmogiškojo potencialo aktyvinimo socialinių įmonių veikloje perspektyvą, kuri atskleidžia socialinio verslumo, kaip asmeninio tobulëjimo galimybès, dimensiją. Siekiama ištirti socialinio verslumo reiškinị ir praktiką socialinio darbo kontekste, kur socialinį verslumą, kaip inovatyvų požiūrị, galima pasitelkti ugdant bendruomenę ir ją keičiant asmeniniu lygmeniu įmonès veikloje dalyvaujantiems žmonèms.

PAGRINDINIAI ŽODŽIAI: socialinis verslumas, socialinis darbas, socialinè sanglauda, socialinis ir dvasinis funkcionavimas, žmogiškasis potencialas, vidiniai žmogaus ištekliai, abipusiškumas.

DOI: http://dx.doi.org/10.15181/tbb.v87i2.2319 


\section{Introduction}

The topicality of the study lies in the fact that social entrepreneurship (SE) organisations and social enterprises have the potential to play an essential role in the improvement of the social cohesion of society, especially in situations of economic breakdown, which usually results in a shortage of the usual financial aid resources for people, and thus facilitates the development of the marginalisation of society on an economic level. As the operational sphere of social work is directly connected with providing assistance to people in need, the necessity arises to find innovative forms of providing assistance in such a situation. The article deals with the principles and practice of social entrepreneurship as a possibility to develop innovative social technologies for the social cohesion of society, both at a community and a personal level.

The aim of the study is to explore the phenomenon and practice of social entrepreneurship in the context of social work, where social entrepreneurship can be used as an innovative approach as a tool for community development, and transformation on a personal level for practitioners and people involved in entrepreneurial activities. The following specific research tasks were set to achieve the aim:

- to define the concept and practice of social entrepreneurship in the context of the social economy;

- to characterise social entrepreneurship as a form of social work, and the connections between caritative social work and social entrepreneurship;

- to analyse the anthropological perspective on activating people's inner resources and human potential in the activities of social enterprises.

\section{Presentation of the research methods}

The following research methods were employed to achieve the aim: the descriptive method was employed to shape the theoretical discussion and interpret the research results based on scientific findings and theories on social entrepreneurship and social work; analysis and synthesis were employed to examine individual problem elements and identify connections between them; induction was used to make scientific assumptions and identify causal relationships from individual elements or facts; deduction was employed to logically systematise and explain the research data. 
Valters Dolacis, Skaidrite Gūtmane, Dace Deizija Rode

\section{The concept and practice of social entrepreneurship in the context of the social economy}

The development of the European social model rests on the concept of SE. The concept has made a significant contribution to the development of the European social economy. SE has a remarkable potential, through its innovative solutions, to play an indispensable role in the social cohesion of EU member states (Terziev, 2020).

SE functions in the context of the social economy, which has been recognised at the level of the European Parliament as the cornerstone of the European social model (Report on a European Social Model for the Future, 2006). The social economy plays an essential role in the European economy, by 1) combining profitability with solidarity; 2) creating high-quality jobs; 3 ) strengthening social, economic and regional cohesion; 4) generating social capital; 5) promoting active citizenship, solidarity and a type of economy with democratic values, which puts people first, in addition to 6) supporting sustainable development and social, environmental and technological innovation (The Social Economy in the European Union: Summary of the Report, 2007, p. 5-6). Thus, SE has developed from particular organisational and legal business formations: cooperatives, mutual societies, non-profit associations, social enterprises, foundations and other entities, in every European country. These businesses, organisations and legal forms share the feature of systematically putting people first, reinvesting most of the profit in the organisation or in a social cause, and having a participatory form of governance (European Commission, Social Enterprises and the Social Economy Going Forward, 2016). Social economy organisations also contribute to the implementation of the European Pillar of Social Rights (European Pillar of Social Rights, 2017).

These types of organisations are known for their capacity to respond to emerging needs and new social demands, particularly in periods of crisis marked by socio-economic transformations, especially in areas where the market seems to fail (Bouchard, 2010a, p. 11). In that way, social enterprises offer support services for economic development: local development, community development, solidary financing, the creation and maintenance of jobs, job insertions, etc. (Bouchard 2010b, p. 117). They are created to meet their members' needs, through applying the principle of self-help; they are companies in which members and users of the activity in question are usually the same. Coming to the definition of social enterprises, the prominent SE researchers Defourny and Nyssens (2010, p. 43) provide the following definition: 'Social enterprises are not-for-profit private organisations providing goods or services directly related to their explicit aim to benefit the community. They generally rely on collective dynamics involving various types of 
stakeholders in their governing bodies, they place a high value on their autonomy and they bear economic risks related to their activity.'

There are three main social functions characteristic of SE organisations: 1) a solidary function, where the economy evolves from being a tool of solidarity to being the aim of the organisation, in order to provide assistance in solving liferelevant issues of the people; 2) a democratic function, where participation potentialities allow organisations to be 'schools of democracy', by which its members are able to develop political skills and civic, communitarian virtues; and 3) a productive function, which differs from that of governmental and for-profit organisations (the price of the products is less than the market price, or there is a lack of competition on the market, despite being relevant market players) (Enjolras, 2010, p. 48-52).

Looking at the definition and functions of social enterprises, it is possible to highlight some main principles of SE in modern expression by social enterprises, the most important being: 1) the primacy of the individual and the social objective over capital; 2) the defence and application of the principles of solidarity, responsibility, reciprocity (social capital) and empowerment; and 3) most of the surplus is used in the pursuit of sustainable development objectives, services of interest to members, or the general interest (see The Charter of Principles of the Social Economy). To conclude, a social enterprise combines entrepreneurial activity with a social purpose, and its main aim is to have a social impact, rather than maximise profits for owners or shareholders. Businesses providing vulnerable people with social services or goods and services are a typical example of a social enterprise.

The Canadian researchers Peter and Tina Dacin, together with Margaret Matear (Dacin et al., 2010, p. 37-57), analysed more than 130 sources of different definitions of social entrepreneurship, and came to the conclusion that there are several focuses that determine the definition of SE, e.g. if a social enterprise is analysed in an economic or management context, its interpretation differs from the approach of social work science, where a social enterprise is defined as a form of social work.

\section{Social entrepreneurship as a form of social work}

SE values are highly consistent with the common EU objectives of social inclusion, and where decent employment, training and re-inclusion should be linked (European Commission, Social Enterprises and their Ecosystems in Europe, 2020). This links SE with the operative sphere of social policy at a national level. SE initiatives have demonstrated that they can greatly improve the social status of disadvantaged people (as in the case, for example, of micro-credit or savings-andloans cooperatives facilitating financial inclusion, and increasing women's influ- 
ence), and that they have a substantial capacity for social innovation, encouraging those facing difficulties to find solutions to their own social problems as regards reconciling their professional and private life, gender equality, the quality of family life, and their ability to care for children, the elderly and people with disabilities (The Social Economy in the European Union: Summary of the Report, 2007, p. 5).

With a national perspective in mind, the attribution of the stated principles of SE has a potential to provide for the practice of social work, for example, in Latvia, its European dimension and innovative practice. Different forms of informal and non-monetary assistance become of great importance in a situation lacking resources, especially strengthening the social capital of people's associations helping to consolidate the personal skills of self-dependence. Here, SE serves as one of the social techniques for the social cohesion of disadvantaged and marginalised groups in society, and therefore can be used as a practical method in the field of social work.

Social entrepreneurship has a close historical connection with social work, and they have common features. The most important of them, social workers and social entrepreneurs, look primarily for solutions to social problems in society (Līcīte, 2018, p. 30-32). Social entrepreneurship integrates the values, theory and practice of social work, combining it with an entrepreneurial approach (Neal, 2015, p. 2). According to Stephanie Berzins, the link between social workers and social entrepreneurs needs to be strengthened, as this can be mutually beneficial (Berzins, 2012, p. 185).

A common feature between social work and social entrepreneurship is also the desire to bring about positive social change in society. According to L. Vilka, social workers promote social change, problem-solving in human relations, social opportunities, and the freedom to increase well-being (Vilka, 2012, p. 120).

Social entrepreneurs need knowledge and understanding not only of social problems and their causes, but also of entrepreneurship. In turn, social workers are involved in the bureaucratic system, not in the business sector (Līite, 2018, p. 30-32), as a result of which they lack a business approach to solving social problems. The social worker's priority is the client's wishes and needs, so he or she often loses the economic perspective, and may use funding inefficiently. As managers or owners of a social enterprise, social workers can face significant problems in balancing social, psychological and economic aspects. However, social entrepreneurs often lack the necessary knowledge and experience in working with the relevant target group. This means that cooperation can be very productive: the social worker can become an important support in social matters, for he or she has a knowledge of the needs of the local community and social issues. It is also emphasised that social work professionals have greater ethical responsibility in 
evaluating the best solutions to social problems (Neal, 2015, p. 6). Effective cooperation between a social entrepreneur and a social worker can also be manifested in measuring the impact of a social enterprise, because in measuring the impact of a social enterprise, it is important not only to evaluate the financial results, but also the social impact. Social workers are trained and experienced in assessing social impact, so they can assess objectively and professionally whether and to what extent a social enterprise has succeeded in achieving social goals (Neal, 2015, p. 7), while an entrepreneur can focus on assessing economic performance.

According to L. Lìîte, social problems in the country can traditionally be solved with the help of market mechanisms, the support of the non-governmental sector, using state funds, and by implementing social work. However, scientific research shows that the state is not able to solve all social problems, but competition for funding is increasing in the non-governmental sector. The private sector, on the other hand, is focused on producing goods and services that provide a profit, rather than improving public welfare. Therefore, the development of social entrepreneurship is an essential tool for solving social problems in an innovative and sustainable way (Līcīte, 2018; Dobele, 2016).

Social entrepreneurship provides an operational platform for the renewal of people's self-dependence skills by learning to do things together, which is a relevant motivational aspect for socially marginal people to solve their social and personal problems. Thus, the social cohesion of disadvantaged and marginalised groups of society, by being involved in social entrepreneurial activities and being placed in the sphere of the productive economy at the community level, contributes to the development of the local community, giving citizens the status of socially active protagonists in their destiny and the local community.

\section{The concept of caritative social work and social entrepreneurship}

Taking an approach based on the European social model, the Latvian Christian Academy has developed a profession of caritative social work, ${ }^{l}$ operating with differing social work and other methodologies, i.e. realising innovative caritative techniques with the goal to stabilise the cohesion of society and the social and spiritual functioning of social objects (Gūtmane, 2009). The profession has also been legalised in the Classification of Occupations (2009) of Latvia, attributing the rights of professional activities to caritative social workers in the system of social welfare in Latvia.

The caritative social worker includes his or her own activity professionally in the EU system of social protection that works against the exclusion of a person, and it sees SE as an integral form of the profession's functional capacities, as SE is 
seen here as an EU-promoted concept, not driven by the profit motive, but by the social benefit to those involved in this activity (the Social Business Initiative), in that way multiplying forms of social capital to overcome 'social depression' at an urban and a rural level (Report on Social Entrepreneurship and Social Innovation in Combating Unemployment, 2014). Here, the tasks of caritative social work and SE complement each other.

Latvia passed the Law on Social Enterprises in 2018, with the goal of promoting the employment of population groups at risk of social exclusion, by creating a favourable economic environment for social enterprises. A social enterprise in Latvia is defined as a limited liability company which has been granted the status of a social enterprise, and which performs economic activities with a favourable social impact (the provision of social services, the creation of an inclusive civil society, the promotion of education, support for science, the protection or promotion of cultural diversity) (see Sociālā uznēemuma likums). The employment of the following groups exposed to the risk of social exclusion is favoured in social enterprises: people with disabilities, people with mental disorders, people from poor families, the unemployed and the long-term unemployed, ethnic minority Roma, prisoners or people released from prison, people with addiction problems, homeless people, victims of human trafficking, refugees and asylum seekers, orphans, parents or guardians caring for a disabled child.

However, the renewal of a person's social functioning, achieved by involvement in social entrepreneurial activities, covers a person's life holistically, starting from the person's inner processes that lead to forming external social relationships. The analysis of this process in the article, therefore, involves an anthropological perspective on activating people's inner resources and human potential in the activities of social enterprises, which also shows the dimension of social entrepreneurship as a tool for personal development.

\section{An anthropological perspective on activating people's inner resources and human potential in the activities of social enterprises}

As was stated before, the objectives of social entrepreneurship are social objectives, not primarily making a profit. The term social here includes the meaning and practice of relationships, consequently a community of people within which the separate, individual person gains a competence for solving problems in life. Consequently, social entrepreneurship is directed towards the stabilisation of human life by bringing him or her into community with other people for solving common problems. In that way, SE acquires an anthropological-oriented character, in which not only aspects of making relationships for obtaining and consolidating compe- 
tence, but also inner stabilising factors of a person that allow the person to stay and survive in these relationships, become of importance.

The objective in social work is to help people, families, groups of people, and society in general, to facilitate or renew their ability to function socially, as well as to create a favourable environment for this functioning, as is stated in the Law on Social Services and Social Assistance of the Republic of Latvia (Sociālo pakalpojumu un sociālās palīdzības likums, 1.19). The definition of caritative social work deepens this definition of social work, because, being similar to that of social work in Latvia, caritative social work includes the renewal of abilities of individuals, families and groups not only to function socially but to function spiritually as well, as is stated in the law (Ibid., 1.32). This setting is essential, because without the recovery of spiritual functioning, it is not possible to ensure the stable renewal of social functioning.

Thus, the approach of caritative social work and social entrepreneurship deepens the operational definition of social work, as social functioning in essence covers a person's life holistically, in its entirety: the person's inner processes and the formation of external social relationships. Therefore, social entrepreneurship becomes a form of social work, as it renews the social functioning of a person. It is done by organising individuals for entrepreneurial activities that are directed towards achieving social objectives, which is how social entrepreneurship differs from classic entrepreneurship. The objectives of stabilising a person's life dominate here, and these objectives are reached by means of reciprocity or mutuality.

It is possible nowadays to notice in the caring professions a crisis of the profession, when the person disappears from the centre of the caring profession, namely, in institutional systems of assistance, the client is no longer at the centre. The place at the centre is taken by the institutional system itself, by its resources and methods, as goals in themselves. The reason for this is the bureaucratising of the system of assistance, in which registering the effectiveness of the assistance provided becomes of importance, as a demand from the leadership regarding the casework of social workers with clients. Because of the limited time that is devoted to caseworking an individual case, this demand for effectiveness is not fully reached. Secondly, the professional crisis in social work is deepened by phenomena when a person is turned into a blunt receiver of assistance (consumer), who is no longer willing to realise his or her human potential. The system does not put into action mechanisms that would help a person unlock their own inner potential to overcome spiritual and social isolation, as it does when working with the processes of the 'client's' inner world. However, social workers are not trained for that. In caritative social work, this sphere of work, in its turn, is brought forward as the primary one. 
Social entrepreneurship as a form of social work is precisely one of the ways to return a 'social client' to the position of a socially active life, by providing him or her with the missing, forgotten, or undeveloped skills of self-determination in solving problems.

Renewing the human identity in this context means restoring the human potential. In its turn, at the foundation of the human identity, to use theological terminology, there lies God's image and likeness (Imago Dei), which is in every person. The image of God is that given constant predisposition in a human being that determines his or her likeness to the very Person of the Triune God and marks out the human being from all God's other created beings on this earth as an inseparable unity of spirit, soul and body. As defined by the Holy Hierarch Theophan the Recluse, human qualities that define a person stem from the image of God: 1) the fact that a person is endowed with reason, intellect, consciousness of his or her 'ego', and the ability to distinguish themselves from other beings; from which results 2) human independence, the sovereign or self-reliant capacity to act within the limits of reasonable freedom, which, in its turn, is connected to the ability to take responsibility; and 3) vitality, since a human being at the moment of his or her origins is not yet the one whose potential he or she can become, so a person develops, forms themselves, becomes (Feofan Zatvornik, 2008, p. 198-199). These are the thoughts, feelings and wishes of the person, which are turned inwards, embedded in the spiritual nature of the person, and transformed into nutrition or elements of growth for the entire person. The most essential quality of human life and the personality is immortality, which includes the limitless potential of possibilities for the perfection of a human being.

The professional activity of all the caring professions, also including that of social entrepreneurship, should be directed towards this renewal and increase of potential for becoming a human person. The potential for human-becoming in a person, in turn, is defined by the likeness of God, which is a changing value (as opposed to the image of God), and should be developed as the growth of humanity in a human, in other words, as a possibility for personal growth. This process takes place gradually, as the renewal of God-likeness or humanity in a person is a process that takes time, and every step in this process is built on the achievement of the previous one, the steps being the levels of spiritual maturation of a person. As St Isaac the Syrian said: 'To the measure of one's living is the perception of truth'2 (Zhuravskiy, 1995, p. 12-13), namely, to the measure of inner purification there unfolds the possibility of accepting the reality; in other words, to whatever extent a person has developed spiritually, to that extent he or she is capable of perceiving the truth, the surrounding reality. Practically, it means we cannot ask of a person (or demand changes from a client) what he or she is not inwardly ready for. 
There are several ways that the likeness of God can be renewed in a person: through the conscience, through reciprocity or community with others, and through work.

Conscience is the core of virtues in a person whose centre is the image of God, an ever-present reminder about the proto-norms of the divine order interwoven in this world. The Holy Hierarch Theophan the Recluse spoke of the conscience as the power of the spirit in a person, which, recognising law and freedom, defines their mutual relationship in a person, and finally when the conscience merges with the will of a person, inner revolt ceases to exist: a person enters into a condition where he or she is filled with the law of love (Feofan Zatvornik, 2008, p. 366-384); or in other words, one has restored the wholeness or integrity of his or her person.

Reciprocity. This principle is especially important for the caritative social worker, as the human being is a being of relations, and he or she is driven by faithmotivated assistance to the 'neighbour', the surrounding people. There exist for him or her two ethical maxims that constitute 'investing' himself in a neighbour, the social dimension of his or her activity: a) the biblical message of Christ that one should act for the sake of 'the least of My brothers' (The Bible, Matthew 25: 35$36,40)$, namely, for the sake of socially 'the least one', the socially excluded one, the poor, the person who is not provided for by society; and the other maxim, b) If you do not love your brother, who is in front of you, how can you love God, Whom you do not see? (paraphrased from the First Epistle of John 4: 20), thus showing that personal relationships with God include at the same time rich inter-subjective aspects in the community of people (Horuzhy, Crisis of Classical European Ethics in the Prism of Anthropology, 2006); here, reciprocity is responsibility for the other. Taken together, these ethical maxims constitute the basis for reciprocity in relations.

Work as a mission. By engaging in work for the good of the community, a person directs his or her personal energies towards the goal, with this breaking the mechanisms of barriers between people, getting out of one's own inner isolation, so that the person may start forming trustworthy and safe social relationships, and in that way to renew his or her social functioning.

The philosopher and anthropologist Tzvetan Todorov says: 'Human nature is to be seen as flexible for radical transformations, if it awakens in the person God's created latent abilities and the necessity for action' (Todorov, 2001). But how can social entrepreneurship put into motion a person socially, his or her mind, heart and will, making the person more active?

First of all, by respecting human dignity, respecting the needs of people, seeing them and advocating for them in the common activity of social enterprise, thus putting social objectives above profit making. When one person devotes himself or 
herself to another person in need, then in the fact of devotion itself there is already a hope included and working, specifically for the other, which allows the person to believe in the self. Secondly, a person gets to know himself or herself when engaged in a common activity with others in trying to solve problems, in communication with others seeing his or her enemies of an inner nature: ability/disability to take care of others (or take responsibility), freedom from fear, aggression, anger, superstition or captivity from them all, thus testing the level of inner freedom; as well as the practice of taking responsibility and a readiness for necessary changes in one's own personality, or a refusal to work with oneself, which has a negative impact on all common activity. The principle of empowerment becomes of importance here, entrusting others with the necessary skills for reaching their own set goals, and setting them free from assistance from outside. Thirdly, stimulating the creativity of a person, developing new or undeveloped skills. Through the process of creativity, a person gains a belief in the personal self, observing unnoticed or forgotten talents, and developing them for the common good of the enterprise. Creativity here functions as a general approach in social entrepreneurship to find innovative solutions for solving individual and social problems. This aspect of creativity, functioning as a general approach in social entrepreneurship, is of special relevance, because only creativity allows for finding innovative solutions to solve life-relevant issues of people in social enterprises in ways that do not make the person more dependent or addicted to the assistance provided, but ensures the freedom of the personality, or, in other words, renews a person's spiritual and social functioning.

However, there are two risks in this situation. First of all, how to awaken one's awareness to willingly 'invest' oneself in the other person, to open the eyes to the real needs of the other, and to have a willingness to help? Here again we come to the principle of reciprocity, as the poverty of the other can awaken reciprocity, compassion for the other. When a person sees real people, their real situation, then reciprocity, compassion, is awakened, and it is awakened by practical activity. The human attitude towards people who experience appalling suffering or needs, like litmus, shows a person's readiness or immaturity to be ready to do something about it. So it is a person's existential reaction to the challenge of suffering in the lives of others, from which reciprocity can be born, compassion for others, a motivation (Kiessling, 1998), so needed for organising oneself to solve life-relevant issues of people in social enterprises.

When reciprocity between people is born, it opens doors for expressing love for the other in practical activity or concern. It allows one to accept the other, and thus reciprocity is exactly what is needed for overcoming the inner isolation of a person, gaining the belief that trustworthy relationships with others exist. Where love is expressed as practical solidarity and concern between people, economy be- 
comes a tool of solidarity, as the aim of a social enterprise is to provide assistance in solving the life-relevant issues of people, individually and commonly. From this, charity is born, which helps as motivation.

The reciprocity born allows for supporting the other when he or she experiences a fall or a failure, catching the other when he or she falls, as the success of all the enterprise depends on the success of an individual person in the social enterprise (the contribution of everyone in the enterprise is essential, as the talents of everyone involved are revealed in the process of communication).

A second risk is that the very intervenor, a social worker or social entrepreneur, is in crisis himself, and cannot reach the other person, the client. One reason may be that the intervenor's awareness of his or her personality is self-sufficient. However, the very intervenor or worker is a person with the same challenges to his personality as is his client or fellow human being. If a worker is not spiritually functioning, then he or she cannot spiritually address the other person. This risk exists for all professionals in the caring professions, and the caritative social worker, like every specialist working with people, is subject to this risk as well. Consequently, the so-called binding reciprocity appears: a practitioner cannot ask from another person changes in the personality if he or she is not undergoing inner changes of a similar nature in his or her personality as well. Otto Scharmer, the leadership theoretician, illustrates this axiom by quoting William O'Brien, lately $\mathrm{CEO}$ of Hanover Insurance, when asked to sum up his most important learning experience in leading profound change: 'The success of intervention depends on the interior condition of the intervenor' (Scharmer, 2010).

What should a specialist do? When a specialist works with people or clients, he or she should have the necessary knowledge of anthropology, and a human understanding of wholeness, taking into consideration the fact that the object of social action is not the impersonal social problem, but his or her own personality, with its life story, situation of life, and with the same necessity to grow, and find stability in his or her self-esteem and humanity. Similarly, the stimulation of aspects of the God-likeness of his or her own personality applies to specialists. Secondly, one needs to have competence in caritative communication, namely, to see the other person as a partner for cooperation who asks for the implementation of reciprocity, in which the specialist is not an instructor but a fellow companion, who himself or herself is growing and improving in the given situation. Thirdly, in order for this process to happen, the specialist should start with his or her own spiritual life, the centre of which is belonging to the Church and its sacraments, which is the main precondition for sustainable professional activity. As the Holy Hierarch Theophan the Recluse indicates, without noble ideals in Christianity, in order to help a person, there is also a need for strength and expertise (know-how) to act, and there is 
a need for active, working wisdom (Teofans Vientuḷieks, 2009, p. 9). Therefore, the basic task is true life in the spirit of Christ, uniting with Christ's divine life in the Church. Christian life is the way active, working communication with God is sustained in the Person of Jesus Christ, by fulfilling in one's life the holy will of God, with the help of God's grace (Ibid., 11).

Theophan the Recluse defines Christian faith overall as divine communication, and active, working communication. For this, there is a need for a struggle with oneself, a willingness and activity to persecute the sin in one's life, and strive decisively for purity and cleanliness, because all the time, unchastity and immorality accumulate in a person's heart, which leads away from love of people (Ibid., 15); such a person is no longer a giver and realiser of reciprocity.

Therefore, in a specialist in whom his or her own spiritual life has started, the awareness appears that not all answers are to be found in himself or herself alone, that he or she is not self-sufficient. Nowadays, in the caring human professions, there is a growing discussion about the increasing necessity of knowing oneself, towards skills of self-reflection that would allow one to become clear about one's motivation, and to cleanse the motivation: what is the goal of my work? It is possible to help others if the specialist forms a caritative attitude in himself, full of respect and compassion for the other person. Cooperation, communication and a common quest for truth are possible if the specialist manages the culture of taking responsibility (confessing sins, universal communication in prayer) and is capable of substitutional place-taking for the sake of his or her clients. Substitutional place-taking ${ }^{3}$ here is the practice of supporting the other in a way so that he or she is encouraged to recover lost spiritual and moral abilities, and the faith in the personal self that is needed for decent self-esteem and for organised activity together.

Such a practitioner in the field of social work and the social entrepreneurship community, who sees the other person in his or her wholeness, and attributes to himself or herself the same qualities, which he asks from others, serves as an element bringing renewal to the whole body of the community.

By stimulating any one of the earlier-mentioned aspects of God-likeness by professional or entrepreneurial activity, together with the reciprocal responsibility of a practitioner for the same spiritual goals as for the other person he or she is addressing, it is possible to stimulate spiritual stability, inner growth and the human potential of the other person, the person's possibility to become more human. In that way, social entrepreneurship, with its mechanisms and the application of its constituting principles in practice, helps to develop human potential, and can be seen in the context as an instrumental tool, a method of social work, since the goal of caritative social work and social entrepreneurship is the stabilisation of a person's life by activating the spiritual and social functioning of a person. 


\section{Conclusions}

1. Raising citizens to the status of active protagonists in their own destiny gives the possibility for people in areas dominated by so-called 'social depression' to overcome it, by organising themselves in groups of social initiatives. In Latvia, the Local Initiative Groups (VRG) movement and community foundations as promoters and initiators of (productive) community initiatives serve as an example. Having accumulated enough social capital, this initiative may accept and develop into a stable form of social entrepreneurship, which, being the European Commission's promoted concept of 'a different approach to entrepreneurship', brings original initiative as part of the nonmarket sub-sector of the social economy into the market or business subsector of the social economy, as well as being one of the social techniques of caritative social work for the social cohesion of disadvantaged and marginalised groups of society.

2. Social enterprises have had and have a fundamental role in the improvement of social cohesion, especially in local communities. They sometimes represent the possibility for economic survival in a region, as is the case of agricultural cooperatives; in other situations, they are the only viable way to solve a social problem. However, SE in Latvia is still a newly emerging concept. The particular interest of the authors is grouped around links between SE and social work on an operational platform. We need to take into consideration the fact that local social enterprises deal with the newly emerging social needs of society, providing assistance to disadvantaged and marginalised groups in society.

3. The article has also shown the anthropological perspective of people's motivation and engagement in social enterprises and the principles of activating a person's inner resources and human potential.

4. Social entrepreneurship is directed towards the stabilisation of human life by bringing him or her into community with other people to solve common problems. SE becomes a form of social work, as it solves the renewal of the social functioning of a person; it is done by organising individuals for entrepreneurial activities directed towards achieving social objectives. Objectives of stabilising a person's life that are reached by means of reciprocity or mutuality dominate here. The stabilisation of human life means renewing human potential. The potential for human-becoming in a person is defined by the likeness of God, and that can be renewed in the person through the conscience, through reciprocity or community with others and work. When reciprocity between people is born, it opens the doors for expressing love of 
the other in practical activity or concern. Where love is expressed as practical solidarity and concern among people, the economy becomes a tool of solidarity, as the aim of a social enterprise is to provide assistance in solving people's life-relevant issues. SE as a form of social work is one of the ways to return a person to the position of a socially active life, by providing him or her with the missing or undeveloped skills of self-determination in solving problems.

5. Social entrepreneurship includes the networking of relationships. One strategic aspect is the enhanced understanding of the wholeness of a person as an anthropological dimension of social entrepreneurship. The networking of relationships only works when it touches the deepest ontological potential of a person (God-likeness), from which emerges the human ability of reciprocity. By ignoring the anthropological dimension, social entrepreneurship turns into ordinary, elementary entrepreneurship. SE, with its mechanisms and the application of its constituting principles in practice, helps to develop human potential, and can be seen as an instrumental tool, a method of social work, as the goal of caritative social work and social entrepreneurship is the stabilisation of a person's life by activating the spiritual and social functioning of a person.

6. To conclude, SE initiatives at a local level can be characterised as players in the field of social cohesion of society, being (1) placed in the sphere of the productive economy on the level of the community, (2) by very marginal people involved in initiatives, (3) administered as small businesses, (4) controlled by people involved with democratic means of decision-making (Pellicer-Sifres et al., 2017, p. 266), and (5) supported by social services and social workers, in order to overcome social exclusion. The last aspects require more detailed research, in order to develop a more thorough vision of attributing the principles of solidarity, responsibility, reciprocity and empowerment to the sphere of social work in Latvia: 1) allowing people to help themselves in organised communitarian ways, becoming empowered in communities in forms of social enterprises, and 2) exploring ways to activate a person's inner resources and human potential in activities of social entrepreneurship. Therefore, the need to explore the role of social, caritative social and community workers becomes of special importance, and also of other members of the caring professions at a national level, in assisting marginal people to come out of stagnation or isolation, and to become active in solving their social, economic and personal problems in forms of productive social enterprises. 
1. The term 'caritative' stems from the Latin caritas (Greek analogue agapē), meaning 'love', 'mercifulness', 'expression of grace', 'active compassion'. The term is used in the Catholic social tradition, which also allows us to speak of it as 'Christian social work'.

2. In original Church Slavonic 'V meru zhitiya bivayet vospriyatiye istini'.

3. See the elaboration of principle of place-taking in the article by K. Kießling 'Deacony: The Presence in the Spirit of God's Solidarity' (Kießling, 2016).

\section{References}

Berzin, S. C. (2012). Where is Social Work in the Social Entrepreneurship Movement? Social Work, Vol. 57(2), p. $185-188$.

Bouchard, M. J. (2010a). Introduction. The Worth of Social Economy. In M. J. Bouchard (ed.). The Worth of the Social Economy. An International Perspective/ CIRIEC, p. 11-19. Bruxelles: P. I. E. Peter Lang.

Bouchard, M. J. (2010b) The evaluation of the social economy in Quebec, with regard to stake-holders, mission and organization identity. In M. J. Bouchard (ed.). The Worth of the Social Economy. An International Perspective/ CIRIEC, p. 111-133. Bruxelles: P. I. E. Peter Lang.

Dacin, P. A., Dacin, T. M., Matear, M. (2010). Social entrepreneurship: Why we don't need a new theory and how we move forward from here. Academy of Management Perspectives, Vol. 24(3), p. 37-57.

Defourny, J., Nyssens, M. (2010). Conceptions of Social Enterprise and Social Entrepreneurship in Europe and the United States: Convergences and Divergences. Journal of Social Entrepreneurship, Vol. 1(1), p. 32-53. Retrieved from http://dx.doi.org/10.1080/19420670903442053

Dobele, L. (2016). The Legal Framework and Support Instruments for Social Entrepreneurship Development in Latvia. Scientific Proceedings of Latvian Christian Academy, Vol. 4: The Innovative Content of Caritative Social Work, p. 234-246. Retrieved from https://kra.lv/proceedings-4-2016/

Enjolras, B. (2010). The Public Policy paradox. Normative Foundations of Social Economy and Public Policies. Which Consequences for Evaluating Strategies? In M. J. Bouchard (ed.). The Worth of the Social Economy. An International Perspective/ CIRIEC, p. 43-62. Bruxelles: P. I. E. Peter Lang.

European Commission. (2016). Social enterprises and the social economy going forward. A call for action from the Commission Expert Group on Social Entrepreneurship (GECES). Directorate-General for Internal Market, Industry, Entrepreneurship and SMEs, 72 p. Retrieved from https://ec.europa.eu/growth/content/ social-enterprises-and-social-economy-going-forward_en

European Commission. (2018). Social enterprises and their ecosystems in Europe. Updated country report: Latvia. Author: L. Līcīte. Luxembourg: Publications Office of the European Union, 124 p. Retrieved from https://ec.europa.eu/social/BlobServlet?docId=20564\&langId=en

European Commission. (2020). Social enterprises and their ecosystems in Europe. Comparative synthesis report. Authors: C. Borzaga, G. Galera, B. Franchini, S. Chiomento, R. Nogales, Ch. Carini. Luxembourg: Publications Office of the European Union, 192 p. Retrieved from https://europa.eu/!Qq64ny

European Pillar of Social Rights. (2017). Retrieved from https:/ec.europa.eu/info/strategy/priorities-2019-2024/ economy-works-people/jobs-growth-and-investment/european-pillar-social-rights/european-pillar-socialrights-20-principles en

Feofan Zatvornik, svyatitel'. (2008). Voploshchonnoye domostroitel'stvo. Opit hristianskoy psihologiyi. Moskva: Pravilo veri. (Duhovnoye naslediye svyatitelya Feofana Zatvornika). [in Russian].

Gūtmane, S. (2009). Karitatīvā sociālā darba metodologiskā paradigma [The methodological paradigm of Caritative social work]. In S. Gūtmane (ed.). Latvian Christian Academy Scientific Proceedings, No. 2: European Social Development: Sacred Foundations of Europe. Social Dialogue. Solidarity. Migration. Cohesion, p. 31-41. Jūrmala: Latvian Christian Academy. 
Valters Dolacis, Skaidrite Gūtmane, Dace Deizija Rode

Horuzhy, S. (2006). Crisis of Classical European Ethics in the Prism of Anthropology. Institute of Synergetic Anthropology, Russia. Retrieved from http://synergia-isa.ru/wp-content/uploads/2011/08/hor crisis ethics. pdf

Kiessling, K. (1998). "To leave the church in the village?" Approaches to an urban Social Pastoral Care. In K. Kiessling. "Love greets you" - On the culture of deacony, p. 55-76. Helsinki: University of Helsinki, Department of Practical Theology.

Kießling, K. (2016). Deacony - Presence in the Spirit of God's Solidarity. In S. Gūtmane (ed.). Scientific Proceedings of Latvian Christian Academy. No. 4: The Innovative Content of Caritative Social Work, p. 12-21. Jūrmala: Latvian Christian Academy. Retrieved from http://kra.lv/proceedings-4-2016/

Līcīte, L. (2018). Pamatnostādnes sociālo problēmu risināšanā: sociālā darba loma sociālajā uzṇēmējdarbībā [Guidelines for Social Problems Solution: The role of Social work in Social Entrepreneurship]. Scientific Proceedings of Latvian Christian Academy, Vol. 5: Dimensions of Caritative Social Work, p. 25-35. Retrieved from https://kra.lv/proceedings-5-2018/

Neal, A. A. (2015). The Intersection of Social Work and Social Enterprise. Journal of Social Work Values and Ethics, Vol. 12(2), p. 1-10.

Pellicer-Sifres, V., Belda-Miquel, S., López-Fogués, A., Boni Aristizábal, A. (2017). Grassroots Social Innovation for Human Development. Journal of Human Development and Capabilities, Vol. 18(2), p. $258-274$. Doi: $10.1080 / 19452829.2016 .1270916$.

Recent evolutions of the Social Economy in the European Union. Study. (2017). European Economic and Social Committee. CIREC-International. Doi: 10.2864/191345.

Report on a European Social Model for the future. (2006). (2005/2248(INI)). Committee on Employment and Social Affairs. Rapporteur: Jose Albino Silva Peneda, Proinsias De Rossa. Final (A6-0238/2006).

Report on Social Entrepreneurship and Social Innovation in combating unemployment (2014/2236(INI)) (30.07.2015.) by Committee on Employment and Social Affairs. Rapporteur: Veronica Lope Fontagne.

Rode, D. D. (2020). Sociālā uzñèmējdarbība kā viena no sociālā darba formām. Maǵistra darbs profesionālā grāda iegūšanai sociālās uzṇēmējdarbības vadībā. Latvijas Kristīgā akadēmija.

Scharmer, O. (2010). The Blind Spot of Institutional Leadership: How to create deep innovation through moving from Egosystem to Ecosystem Awareness. Paper prepared for: World Economic Forum, Annual Meeting of the New Champions, Tianjin, People's Republic of China, September 2010. Retrieved February 15, 2017 from http://www.ottoscharmer.com/sites/default/files/2010_DeepInnovation_Tianjin.pdf

Social Business Initiative - Creating a favourable climate for social enterprises, key stakeholders in the social economy and innovation \{SEC(2011) 1278 final\}. Communication from the Commission to the European Parliament, the Council, the European Economic and Social Committee and the Committee of the Regions. 25.10.2011 COM(2011) 682 final. European Commission, Brussels. Retrieved from http:// ec.europa.eu/ internal market/social business/docs/COM2011 682 en.pdf

Social Economy for the full inclusion of people with disabilities. Best Practice Guide. (2020). Social Economy Europe. Brussels, 46 p. Retrieved from https://www.socialeconomy.eu.org/wp-content/uploads/2020/12/ SEE SocialEconomy-4-the-inclusion-of-People-with-Disabilities.pdf

Sociālā uzṇēmuma likums [Law on Social Enterprise]. (2017). Latvijas Vēstnesis, Vol. 212, 25.10.2017. [comes into force: 01.04.2018.] [in Latvian].

Sociālo pakalpojumu un sociālās palīdzības likums (2002). Latvijas Vēstnesis, Vol. 168 (2743), 19.11.2002; Ziņotājs, Vol. 23, 12.12.2002.] [comes into force: 01.01.2003.] [in Latvian].

Teofans Vientuḷnieks, svētnieks. (2009). Ceḷš uz pestǐšanu (İss askētiskas apraksts). Rīga: Latvijas Pareizticīgās Baznīcas Sinode [in Latvian].

Terziev, V., Bencheva, N., Stoeva, T., Georgiev, M. (2020). Developing Social Entrepreneurship in the EU: A Cross-Country Analysis. SSRN Electronic Journal, Vol. 6, p. 37-44. Doi: 10.2139/ssrn.3525681

The Charter of Principles of the Social Economy promoted by the European Standing Conference on Cooperatives, Mutual Societies, Associations and Foundations (CEP-CMAF) CIRIEC. (2000).

The Lisbon Declaration: Social Innovation as a Path to a Sustainable, Resilient and Inclusive Europe. (2018). Retrieved from https://media.nesta.org.uk/documents/Lisbon_Declaration_on_Social_Innovation.pdf

The Social Economy in the European Union (CESE/COMM/05/2005). (2007). Report drawn up for the European Economic and Social Committee (EESC) by CIRIEC (International Centre of Re-search and Information on the Public, Social and Cooperative Economy. 


\section{SOCIAL ENTREPRENEURSHIP AS A FORM OF SOCIAL WORK FOR THE SOCIAL...}

The Social Economy in the European Union: Summary of the Report. (2007). Drawn up for the European Economic and Social Committee by CIRIEC (International Centre of Research and Information on the Public, Social and Cooperative Economy (DI CESE 96/2007 EN/o.

Todorov, T. (2001). Life in common. An essay in general anthropology. Lincoln and London: University of Nebraska Press.

Vilka, L. (2012). Sociālā darba izglîtībai Latvijā 20 gadu: vēsturisks atskats un ieskats mūsdienu problemātikā LZA Vēstis, Vol. 4. Herald of Latvian Academy of Sciences.

Zhuravskiy, I., protopresvyter. (1995). Tayna Carstviya Bozhiya ilyi zabitiy put' istinnago Bogopoznaniya. Riga: [without publisher]. [in Russian].

Valters Dolacis - lecturer, master of Humanities (Theology), Latvian Christian Academy.

E-mail: kursi@kra.lv 